\title{
Characterization of six types of dried sea cucumber product from different countries
}

\author{
Thu Truong ${ }^{1 *}$, Thuy Le ${ }^{2}$ \\ ${ }^{1}$ Department of Food Science and Technology, Tokyo University of Marine Science and Technology, Tokyo, Japan \\ ${ }^{2}$ College of Aquaculture and Fisheries, Can Tho University, Can Tho, Vietnam
}

\begin{abstract}
How to cite this paper: Truongs, T., Le, T. (2019) Characterization of six types of dried sea cucumber product from different countries. International Journal of Food Science and Agriculture, 3(3), 220-231.
\end{abstract}

DOI: $10.26855 /$ ijfsa.2019.09.011

*Corresponding author: Thu Truong, College of Aquaculture and Fisheries, Can Tho University, Can Tho, Vietnam. Tell: +84 799690512

Email: ttmthu@ctu.edu.vn

\begin{abstract}
The character of six types of dried sea cucumber product and soaked sea cucumber sample in different countries, namely, Indonesia, Mexico, Australia and Japan (Hokkaido, Kansai and Aomori prefectures) was determined. Proximate composition, SDS-PAGE, amino acids and mineral contents, body size, physical properties and color of dried sea cucumber products and soaked sea cucumber samples were investigated. As a result, dried sea cucumbers contained $42.0-66.9 \%$ protein, $1.83-5.86 \%$ lipid, $8.62-37.3 \%$ ash, 12.2 - $18.4 \%$ moisture and $4.56-7.24 \%$ carbohydrate. SDS-PAGE showed that protein from dried sea cucumbers were gelatin, consisting of $\alpha$ chain $(115 \mathrm{kDa})$ and $\beta$ chain $(200 \mathrm{kDa})$. The degradation of $\alpha$ chain and $\beta$ chain of gelatin was observed from SDS-PAGE for all of soaked sea cucumber samples. All of dried sea cucumber products were abundant in glycine, glutamic acid, aspartic acid and proline, accounted for $57.6-63.3 \%$ in total amino acids and rich in magnesium, calcium, potassium and sodium which accounted for $99.91 \%$ $99.98 \%$ in total mineral content. $L^{*}, a^{*}$ and $b^{*}$ color values of six types of soaked sea cucumber sample ranged from $16.3-38.3,0.30-4.58$ and 2.78 - 8.54, respectively. The best texture (the highest springiness of 1.025); the highest weight $(175 \mathrm{~g})$, length $(154 \mathrm{~mm})$, body wall thickness $(14.0 \mathrm{~mm})$, height of spine $(8.16 \mathrm{~mm})$ and rehydration ratio (11.9) in soaked sea cucumber in Hokkaido product contribute to its best quality and highest commercial values.
\end{abstract}

\section{Keywords}

Dried sea cucumber, proximate composition, amino acids, mineral contents, physical properties

\section{Introduction}

Sea cucumbers, belonging to the phylum Echinodermata, are marine animals living in seawater. Since sea cucumbers will be subject to autolyze rapidly after leaving from seawater, more than $80 \%$ of fresh sea cucumbers are processed into dried products [1]. Sea cucumbers or dried products are called as namako in Japan, haishen in China, teripang in Indonesia, trepang in Malaysia, beche-de-mer in French, plingkao in Thailand, Hai-som in Vietnam and sandfish according to international market. In recent years, the demand of sea cucumbers increases in China, Japan, Hong Kong, Singapore and South Korea due to its high nutritional values and high bioactive compounds such as collagens, mucopolysaccharides, glycosaminoglycans, saponins, vitamins and minerals [2].

On the other hand, Japan also produced and exported dried sea cucumbers in Hokkaido, Aomori, Kansai and other prefectures. In addition, the retail prices per kilogram of Japanese dried sea cucumbers produced in Hokkaido, Aomori and Kansai prefectures, Japan were USD 705, USD 705 and USD 394, respectively in Hong Kong market in 2009 [3]. In addition, [4] demonstrated that Indonesia is one of the largest exporter dried sea cucumbers in the world. The price of dried sea cucumber per kilogram produced in Indonesia was USD 300 - 500. Moreover, [5] reported that the price per kilogram of Australasian sea cucumber, Australostichopus mollis can reach around USD 275 dry weight in Asia. The 
different prices of dried sea cucumber products depend on species, body size and quality of processing [6]. [7] reported that each sea cucumber species has unique texture characteristics, which contribute to the desirability of sea cucumbers [8] and its commercial values [3]. In addition, [9] revealed that customers favor a uniformly shape and large size of dried sea cucumbers. Moreover, [3] illustrated that the demand of Japanese dried sea cucumbers increases due to their large spines and thick flesh. From those mentions above, it can be forecasted that there is a relationship between the commercial values of the dried sea cucumbers and their characters.

Some studies on dried sea cucumber products, including nutritional quality of products produced in Japan [10] and Indonesia [11]however, studies on nutrition value of Indonesian sea cucumbers are still beneficial due to the great diversity and uniqueness of each species. The present work was intended to obtain information about chemical composition and fatty acid profile of 4 (four; texture properties of product produced in Hokkaido [8] as well as the commercial values of products produced in Japan [3], Australia [5] and Indonesia [4] have been studied. However, the information on the relationship between the dried sea cucumber characters and their commercial values has rarely been reported. Therefore, the aim of this study was to determine the character of six types of dried sea cucumber products produced in different countries to evaluate the relationship between their characters and commercial values. Various parameters such as the proximate composition, amino acids and mineral contents, SDS-PAGE, body size, physical properties and color of six types of dried product and soaked sea cucumber sample were investigated.

\section{Materials and Methods}

\subsection{Materials}

Six types of dried sea cucumber product produced in different countries, namely, Mexico, Australia, Indonesia and Japan (Hokkaido, Kansai and Aomori prefectures), were purchased from Singapore. A total of 8 individual dried sea cucumbers of each product were used. Four of these were individually frozen at $-30{ }^{\circ} \mathrm{C}$ in freezer for $24 \mathrm{~h}$ and placed in a freeze drier for $72 \mathrm{~h}$. Freeze-dried samples were ground using a grinder into fine powder and kept in screw top vials at $-30{ }^{\circ} \mathrm{C}$. The other four were soaked in distilled water at $4{ }^{\circ} \mathrm{C}$ until reaching a constant rehydration ratio to produce soaked sea cucumber samples. Dried sea cucumber powder and soaked sea cucumber samples were used for further analysis.

\subsection{Soaking process}

Soaked sea cucumber sample was prepared according to the method described by [8] with some modifications. Dried sea cucumber sample was weighed, and body length and height of spines were measured before soaking in $4{ }^{\circ} \mathrm{C}$ ice distilled water using a sample to water ratio of 1:50 (w/v). The sample was kept in refrigerator at $4{ }^{\circ} \mathrm{C}$ and the distilled water was replaced every day. At every day interval, sea cucumber was taken and removed excess water from their surfaces by using tissue paper, weighed and calculated the rehydration ratio, and then heated at $92{ }^{\circ} \mathrm{C}$ for 30 min in water bath and immediately placed back into the soaking ice distilled water at $4{ }^{\circ} \mathrm{C}$. Intestine of sea cucumber was removed at $4^{\text {th }}$ day soaking period. The clean body wall of sea cucumber was soaked and heated over a period until reach a constant rehydration ratio. Four replicates were performed for each product and mean values were calculated. The rehydration ratio was determined every day and calculated as following equation.

$$
\text { Rehydration ratio }=\frac{\mathrm{M}}{\mathrm{Mo}}
$$

Where M, Mo were the weights of each sea cucumber after every day of soaking (g) and its dried sea cucumber ( $\mathrm{g}$ ) respectively.

\subsection{Body size of dried and soaked sea cucumber samples}

Length, height of spines and body wall thickness were measured by using a digital caliper $(0-150$ mm), while digital balance was used for weight. In respect of spines, fifteen spines were measured and an average was calculated for each sea cucumber. For body wall thickness, the thickness of half of the body wall of samples was measured every $0.5 \mathrm{~cm}$ along the axis, and the mean body wall thickness was calculated. Each product was done in quadruplicate.

\subsection{Color measurement of soaked sea cucumber samples}

Color of soaked sea cucumber samples was measured using a color reader CR-13 (Konica Minolta, INC, Japan). Tests were carried out in four replications for each product. An average reading for each replication was calculated from measuring four different points along the body length of soaked sea cucumber. Color values were expressed as Hunter 
$\mathrm{L}^{*}, \mathrm{a}^{*}, \mathrm{~b}^{*}$, respectively, where $L^{*}$ (lightness), $a^{*}$ (redness), and $b^{*}$ (yellowness).

\subsection{Texture measurement of soaked sea cucumber samples}

Texture measurement of soaked sea cucumber samples was derived from that of [12]a rapid and non-invasive NMR and MRI method was introduced to analyze the rehydration process for dried sea cucumber. The spin-spin relaxation time (T2 with some modifications by using a Creep Meter (RHEONER II RE2-33005B, Yamaden Co., Ltd., Tokyo, Japan). Each soaked sea cucumber was cut into four pieces with the size of $20 \mathrm{~mm}$ x $10 \mathrm{~mm}$ x $5 \mathrm{~mm}$. A cylindrical type plunger (diameter $40 \mathrm{~mm}$ ) was used to compress twice at a speed of $1 \mathrm{~mm} / \mathrm{s}$ until it reached $30 \%$ of the piece height. Texture parameters of soaked sea cucumber such as hardness, springiness, cohesiveness and chewiness were derived from the Texture Profile Analysis (TPA) curve. Tests were done in four replications.

\subsection{Proximate composition analysis}

Dried sea cucumber samples were determined proximate composition according to [13]. Soaked sea cucumbers were used for determining moisture content. Moisture content was determined by drying samples in an oven at $105 \pm 2 \mathrm{oC}$ until reach a constant weight; crude ash content by incinerating in a muffle furnace at $550{ }^{\circ} \mathrm{C}$ for $24 \mathrm{~h}$; nitrogen content by Kjeldahl method and crude protein content was calculated as 6.25 times $\% \mathrm{~N}$; lipid by the method of [14] using chloroform/methanol $(2: 1, \mathrm{v} / \mathrm{v})$; crude carbohydrates were calculated by differences. All analyses were carried out in four replications.

\subsection{Sodium dodecyl sulfate polyacrylamide gel electrophoresis (SDS-PAGE)}

SDS-PAGE was performed as previously described by [15] with some modifications. Briefly, $0.1 \mathrm{~g}$ of dried sea cucumber powder or $2 \mathrm{~g}$ of soaked sea cucumber sample was dissolved in $10 \mathrm{~mL}$ solution of $20 \mathrm{mM}$ Tris- $\mathrm{HCl}(\mathrm{pH}$ 8.8), 8 M Urea, 2\% SDS, $2 \%$ mercapethanol by boiling for $2 \mathrm{~min}$, and then shook for one week. Sample was dialyzed and centrifuged at 10,000 g for $10 \mathrm{~min}$. Protein concentration in supernatant was adjusted to $8 \mathrm{mg} / \mathrm{ml}$ and mixed with sample buffer (20 mM Tris-HCl, pH 8.8, 8 M Urea, 2\% SDS, 2\% mercapethanol, 20\% glycerol, $0.4 \%$ bromophenol blue) at a ratio of 2:1 (v/v) for dried sea cucumber and 3:1 (v/v) for soaked sea cucumber sample. $20 \mathrm{~mL}$ of protein sample was applied to each well in polyacrylamide gel 12.5\% (E-12.5L, e-PAGEL; Atto Corporation, Japan) and subjected to electrophoresis at a constant current of $20 \mathrm{~mA}$ per gel. After electrophoresis, gel was stained with $0.1 \%$ (w/ v) Coomasive Brilliant Blue R-250 in 30\% (v/v) methanol and 10\% (v/v) acetic acid for overnight and destained with $30 \%(\mathrm{v} / \mathrm{v})$ methanol and $10 \%(\mathrm{v} / \mathrm{v})$ acetic acid. High molecular weight markers (Thermo Scientific, EU) were used to estimate the molecular weight of proteins.

\subsection{Amino acid composition of dried sea cucumber products}

The total amino acids of dried sea cucumber products was determined according to the method of Zhong, Khan, \& Shahidi, (2007) with some modifications. $10-20 \mathrm{mg}$ of dried sea cucumber powder was hydrolyzed in $1 \mathrm{~mL}$ of $6 \mathrm{~N}$ $\mathrm{HCl}$ at $110{ }^{\circ} \mathrm{C}$ for $22 \mathrm{~h}$ under vacuum. The hydrolysate sample was neutralized with $6 \mathrm{~N}$ and $2 \mathrm{~N} \mathrm{NaOH}$. Final volume was made up at $10 \mathrm{~mL}$ with ionized exchange water, filtered through syringe filter $(0.45 \mu \mathrm{m})$ and stored at $-30{ }^{\circ} \mathrm{C}$ until analyze. Total amino acids was measured by high performance liquid chromatography (Prominence, Shimadzu Corporation) with a column (Shim-pack Amino-Li, $100 \mathrm{~mm}$ x $6.0 \mathrm{~mm}$ I.D., column temperature, $39.0^{\circ} \mathrm{C}$ ) and pre-column (Shim-pack ISC-30/S0504 Li, 50mm x 4.0mm i.d. Shimadzu). Amino acids were detected using a fluorescence detector (RF-10AXL; Shimadzu).

\subsection{Mineral composition of dried sea cucumber products}

Mineral analysis was conducted according to the method of [17] with some modifications. $50 \mathrm{mg}$ of ash sample was digested with $1 \mathrm{~mL}$ of hydrogen peroxide $\left(\mathrm{H}_{2} \mathrm{O}_{2}\right)$ and $1 \mathrm{~mL}$ of nitric acid $\left(\mathrm{HNO}_{3}\right)$ and heating at $60{ }^{\circ} \mathrm{C}$ in water bath for 2 hours. Then, digested solution was filtered by using filter paper and made up to $50 \mathrm{~mL}$ by using ionized exchange water. Mineral composition was analyzed by using inductively coupled plasma mass spectrometry (ICP- MS).

\subsection{Statistical analysis}

All analyses were repeated in quadruplicate. The results were expressed as mean values \pm standard error (SE). The data were analyzed using SPSS 18.0 software and one-way analysis of variance (ANOVA) was carried out and followed by Duncan's multiple range tests. A value of $\mathrm{p}<0.05$ was used to indicate significant difference. 


\section{Results and Discussion}

\subsection{Proximate composition of dried sea cucumber products}

The proximate composition of six types of dried sea cucumber product is presented in Table 1. Significant variations $(p<0.05)$ between the proximate compositions among the products, excepted for crude carbohydrate content $(p<0.05)$ was found. Crude protein, lipid, crude ash, moisture and crude carbohydrate contents were in the range $42.0-66.9 \%$, $1.83-5.86 \%, 8.62-37.3 \%, 12.2-18.4 \%$ and $4.56-7.24 \%$, respectively. These results compared well with 40.7 $63.3 \%, 0.3-10.1 \%$ and $15.4-39.6 \%$ of protein, lipid and ash contents, respectively reported in previous study for eight dried sea cucumber species [18]. From the results, it can be seen that the highest protein content of dried sea cucumber was observed for Hokkaido product $(66.9 \pm 1.6 \%$ ), which was similar to $62.7 \pm 1.5 \%$ and $62.9 \pm 1.8 \%$ of protein contents in Indonesia and Kansai products, respectively, whereas the lowest was found in Mexico product (42.0 $\pm 1.4 \%)$ In addition, the similar higher lipid contents were noticeable in Hokkaido and Kansai products $(5.86 \pm 0.7 \%$ and $4.55 \pm 0.7 \%$, respectively) than the other four products, which were no significant different $(\mathrm{p}<0.05)$. Moreover, the highest ash content in Mexico product was 37.3 $\pm 0.9 \%$, followed by Aomori product $(26.0 \pm 0.8 \%$ ), and then Australia product $(17.4 \pm 0.4 \%)$. Furthermore, the highest and lowest moisture contents were noted in Indonesia product $(18.4 \pm 0.3 \%)$ and Aomori product $(12.2 \pm 0.4 \%)$, respectively.[19] reported that moisture and lipid contents in some dried sea cucumber species, such as Holothuria atra, Holothuria scabra, Actinopyga echinites were lower than those for all of dried sea cucumbers in the current study, while the similar protein and ash contents were noted. The discrepant proximate composition in dried sea cucumber products is governed by many factors such as species, seasons, feeding conditions, local environmental factors and regions [19] and processing [20] and reduce energy consumption, we dried sea cucumber using three different drying methods, namely, electrohydrodynamic (EHD. In addition, high ash contents in Mexico and Aomori products may be due to the salt treatment during dried sea cucumber production [8] sand contamination in gut cavity [21] and calcareous ring in sea cucumbers [22]. Results indicated that dried sea cucumbers had high protein, ash and low fat levels [18].

Table 1. Proximate composition of six types of dried sea cucumber product

\begin{tabular}{llllll}
\hline Products & Protein (\%) & Lipid (\%) & Ash (\%) & Moisture (\%) & Carbohydrate (\%) \\
\hline Hokkaido & $66.9 \pm 1.6^{\mathrm{a}}$ & $5.86 \pm 0.7^{\mathrm{a}}$ & $8.62 \pm 0.6^{\mathrm{e}}$ & $13.3 \pm 0.2^{\mathrm{cd}}$ & $5.34 \pm 0.5^{\mathrm{a}}$ \\
Indonesia & $62.7 \pm 1.5^{\mathrm{a}}$ & $1.83 \pm 0.3^{\mathrm{c}}$ & $11.9 \pm 0.5^{\mathrm{d}}$ & $18.4 \pm 0.3^{\mathrm{a}}$ & $5.21 \pm 1.5^{\mathrm{a}}$ \\
Mexico & $42.0 \pm 1.4^{\mathrm{c}}$ & $2.37 \pm 0.5^{\mathrm{c}}$ & $37.3 \pm 0.9^{\mathrm{a}}$ & $12.9 \pm 0.3^{\mathrm{cd}}$ & $5.51 \pm 1.1^{\mathrm{a}}$ \\
Australia & $56.5 \pm 1.4^{\mathrm{b}}$ & $3.14 \pm 0.3^{\mathrm{bc}}$ & $17.4 \pm 0.4^{\mathrm{c}}$ & $15.7 \pm 0.3^{\mathrm{b}}$ & $7.24 \pm 0.8^{\mathrm{a}}$ \\
Kansai & $62.9 \pm 1.8^{\mathrm{a}}$ & $4.55 \pm 0.7^{\mathrm{ab}}$ & $13.3 \pm 0.6^{\mathrm{d}}$ & $13.9 \pm 0.4^{\mathrm{c}}$ & $5.33 \pm 1.5^{\mathrm{a}}$ \\
Aomori & $54.5 \pm 1.3^{\mathrm{b}}$ & $2.77 \pm 0.4^{\mathrm{c}}$ & $26.0 \pm 0.8^{\mathrm{b}}$ & $12.2 \pm 0.4^{\mathrm{d}}$ & $4.56 \pm 0.9^{\mathrm{a}}$ \\
\hline
\end{tabular}

Data are expressed as mean \pm standard error $(n=4)$. Different superscripts in the same column indicate statistical differences $(\mathrm{p}<0.05)$.

\subsection{SDS-PAGE of dried and soaked sea cucumber samples}

SDS-PAGE analysis of proteins from dried and soaked sea cucumber samples under reducing conditions are shown in Figure 1 and Figure 2, respectively. Lane M, H, ME, I, AU, K and AO were proteins from Marker, Hokkaido, Mexico, Indonesia, Australia, Kansai and Aomori products, respectively. For dried sea cucumber products, it can be seen that protein from Hokkaido, Kansai and Aomori products consisted of a chain and b chain of around $115 \mathrm{kDa}$ and $200 \mathrm{kDa}$, respectively and actin around $45 \mathrm{kDa}$ (Fig. 1a). However, Mexico, Indonesia and Australia products had only a chain and actin (Figure 1). The results were similar to many previously studies which reported that collagen composed a chain and $\beta$ chain and classified as type I collagen in many sea cucumber species, including sea cucumber Stichopus japonicas [18], giant red sea cucumber Parastichopus californicus [23], Stichopus monotuberculatus [24] pepsin-solubilized collagen of Stichopus monotuberculatus (PSC-Sm. However, it was suggested that $\alpha$ chain and $\beta$ chain appeared to be gelatin in dried sea cucumbers in this study because of the completely degradation and gelatinization of collagen into gelatin occurred during boiling process in dried sea cucumber production [25]. For soaked sea cucumber samples, the SDS-PAGE pattern showed that protein from all of soaked sea cucumber samples had only actin around $45 \mathrm{kDa}$ (Figure 2), and there was no difference in pattern amongst the samples. Thus, the degradation of a chain and b chain was occurred during soaking and heating process. The result was similar to study reported by [26], which demonstrated that 
increased heating time leads to completely disappearance of gelatin components ( $\beta$ and $\alpha$ chains). Moreover, the SDSPAGE pattern showed a little smearing which may be due to the interfering of polysaccharides [27].

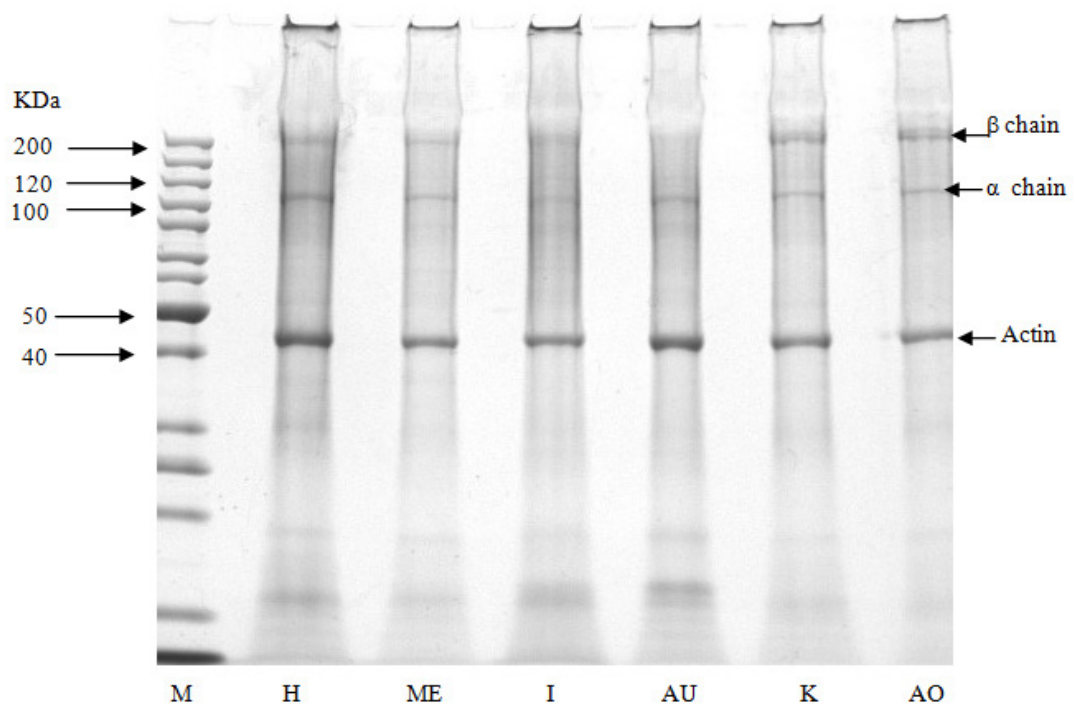

Figure 1. SDS-PAGE pattern of six types of dried sea cucumber product Lane M, high molecular weight marker; Lane H, dried sea cucumber product from Hokkaido; Lane ME, dried sea cucumber product from Mexico; Lane I, dried sea cucumber product from Indonesia; Lane AU, dried sea cucumber product from Australia; Lane K, dried sea cucumber product from Kansai; Lane AO, dried sea cucumber product from Aomori.

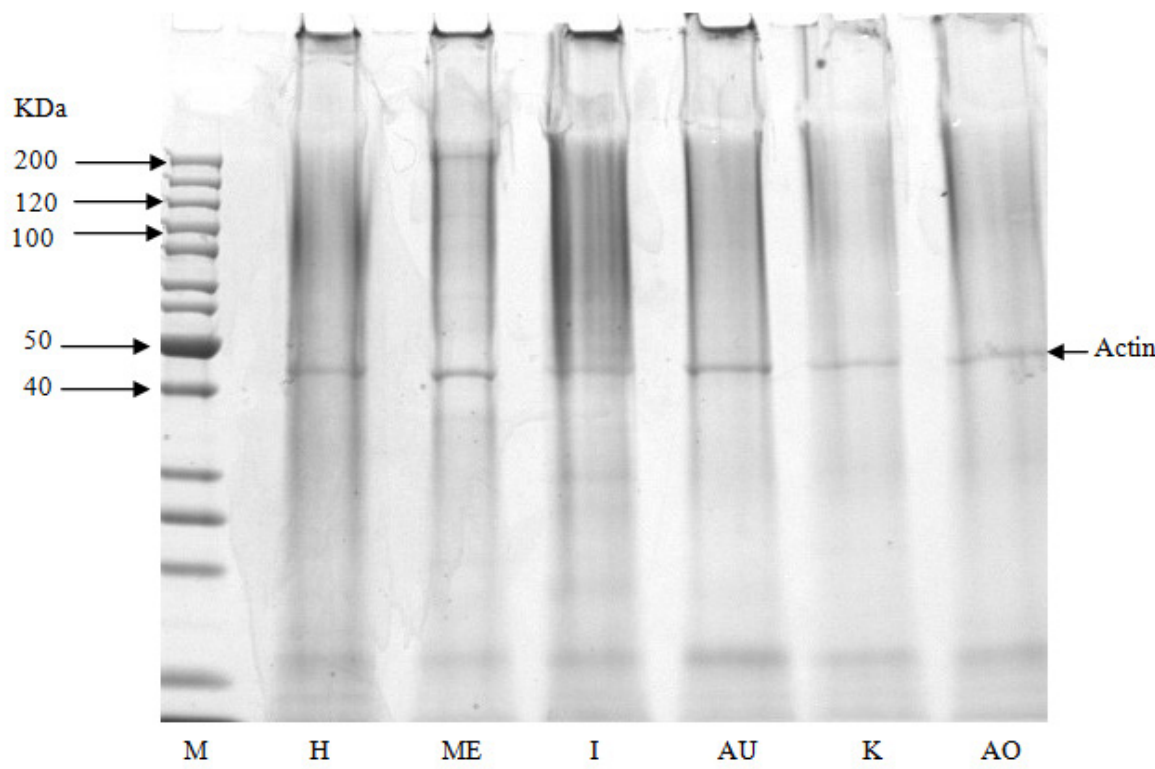

Figure 2. SDS-PAGE pattern of six types of soaked sea cucumber sample Lane M, high molecular weight marker; Lane H, dried sea cucumber product from Hokkaido; Lane ME, dried sea cucumber product from Mexico; Lane I, dried sea cucumber product from Indonesia; Lane AU, dried sea cucumber product from Australia; Lane K, dried sea cucumber product from Kansai; Lane AO, dried sea cucumber product from Aomori.

\subsection{Amino acid composition of dried sea cucumber products}

The amino acid compositions of six types of dried sea cucumber products are shown in Table 2. Total amino acids (TAAs) ranged from $12251 \pm 265 \mathrm{mg} / 100 \mathrm{~g}$ to $22364 \pm 539 \mathrm{mg} / 100 \mathrm{~g}$ with the highest TAAs found in Hokkaido and Kansai products, while the lowest one was observed for Mexico product. From the results, it can be seen that most abundant 
amino acids in all products are glycine, glutamic acid, aspartic acid and proline. The concentration of these four amino acids constituted $(58.9 \%, 63.3 \%, 58.6 \%, 59.4 \%, 58.9 \%$ and $57.6 \%)$ of the TAAs in Hokkaido, Indonesia, Mexico, Australia, Kansai and Aomori products, respectively. Glycine was the most abundant amino acid in all products with the similar highest concentration was observed for Hokkaido (4629 $\pm 179 \mathrm{mg} / 100 \mathrm{~g})$ and Indonesia (4534 $\pm 166 \mathrm{mg} / 100$ g) products, while the lowest content was observed for Mexico product (2299 $\pm 84.6 \mathrm{mg} / 100 \mathrm{~g})$. Glutamic acid was the second most abundant amino acids in all products, ranged from $2130 \pm 36.5 \mathrm{mg} / 100 \mathrm{~g}$ to $4083 \pm 192 \mathrm{mg} / 100 \mathrm{~g}$. Aspartic acid and proline were the third and the four most abundant amino acids in Hokkaido and Mexico product, respectively, while the opposite trend was found in Indonesia product, with no different between these amino acids in Australia, Kansai and Aomori products. Glycine and glutamic acid trends in the present study followed the trend of many previous studies for amino acid compositions in dried sea cucumbers, which were reported by [28]; [18]; [16] and [1], however, these authors found that arginine was the third most abundant amino acid instead of proline or aspartic acid in present study. The minimum content of amino acids were occurred in the case of histidine and hydroxylysine, which ranged from $73.7 \pm 9.2 \mathrm{mg} / 100 \mathrm{~g}$ and $75.6 \pm 11.1 \mathrm{mg} / 100 \mathrm{~g}$ to $180 \pm 25.8 \mathrm{mg} / 100 \mathrm{~g}$ and $266 \pm 31.1 \mathrm{mg} / 100 \mathrm{~g}$, respectively, while [16] found that the two amino acids investigated to be histidine and orginine. In addition, histidine, lysine and methionine were three limiting amino acids in eight dried sea cucumber species [18]. Cystine and tryptophan were not detected in all products, which was very close to the previous study of [29] and [28].

Table 2. Amino acid profiles of six types of dried sea cucumber product (mg/100 g dried sea cucumber)

\begin{tabular}{|c|c|c|c|c|c|c|}
\hline Amino acid & Hokkaido & Indonesia & Mexico & Australia & Kansai & Aomori \\
\hline Aspartic acid & $2402 \pm 51.0^{\mathrm{a}}$ & $2079 \pm 38.9^{\mathrm{b}}$ & $1555 \pm 41.1^{\mathrm{c}}$ & $1495 \pm 40.5^{\mathrm{c}}$ & $2511 \pm 88.6^{\mathrm{a}}$ & $2144 \pm 68.5^{b}$ \\
\hline Hydroxyproline & $1372 \pm 22.2^{\mathrm{a}}$ & $1073 \pm 59.5^{\mathrm{b}}$ & $1123 \pm 36.0^{b}$ & $984 \pm 77.0^{b}$ & $1334 \pm 14.4^{\mathrm{a}}$ & $1320 \pm 35.3^{a}$ \\
\hline Threonine* & $1089 \pm 57.2^{\mathrm{a}}$ & $894 \pm 20.8^{b}$ & $342 \pm 17.1^{\mathrm{d}}$ & $482 \pm 24.2^{\mathrm{c}}$ & $1059 \pm 60.7^{\mathrm{a}}$ & $1021 \pm 28.2^{a}$ \\
\hline Serine & $1125 \pm 16.6^{\mathrm{a}}$ & $734 \pm 13.2^{c}$ & $416 \pm 37.8^{\mathrm{e}}$ & $596 \pm 40.2^{d}$ & $1183 \pm 58.9^{\mathrm{a}}$ & $983 \pm 30.6^{\mathrm{b}}$ \\
\hline Glutamic acid & $3765 \pm 96.9^{a}$ & $4035 \pm 154^{\mathrm{a}}$ & $2130 \pm 36.5^{\mathrm{c}}$ & $2402 \pm 160^{\mathrm{c}}$ & $4083 \pm 192^{\mathrm{a}}$ & $2947 \pm 72.5^{b}$ \\
\hline Proline & $2239 \pm 112^{b}$ & $2602 \pm 38.3^{\mathrm{a}}$ & $1189 \pm 50.6^{\mathrm{d}}$ & $1597 \pm 94.6^{\mathrm{c}}$ & $2421 \pm 82.0^{\mathrm{ab}}$ & $2318 \pm 104^{\mathrm{ab}}$ \\
\hline Glycine & $4629 \pm 179^{\mathrm{a}}$ & $4534 \pm 166^{\mathrm{ab}}$ & $2299 \pm 84.6^{\mathrm{d}}$ & $3039 \pm 152^{\mathrm{c}}$ & $4153 \pm 162^{b}$ & $4212 \pm 169^{b}$ \\
\hline Alanine & $675 \pm 24.2^{\mathrm{b}}$ & $812 \pm 42.4^{\mathrm{a}}$ & $335 \pm 23.2^{\mathrm{e}}$ & $556 \pm 7.9^{\mathrm{cd}}$ & $630 \pm 45.2^{\mathrm{bc}}$ & $482 \pm 45.9^{d}$ \\
\hline Valine* & $796 \pm 36.7^{b}$ & $703 \pm 26.5^{\mathrm{c}}$ & $559 \pm 21.3^{\mathrm{d}}$ & $341 \pm 11.8^{\mathrm{e}}$ & $835 \pm 27.7^{\mathrm{ab}}$ & $913 \pm 40.9^{\mathrm{a}}$ \\
\hline Methionine* & $379 \pm 19.8^{\mathrm{b}}$ & $352 \pm 11.0^{\mathrm{b}}$ & $396 \pm 32.8^{\mathrm{b}}$ & $441 \pm 43.7^{b}$ & $422 \pm 44.6^{\mathrm{b}}$ & $577 \pm 28.8^{\mathrm{a}}$ \\
\hline Isoleucine* & $603 \pm 15.8^{\mathrm{a}}$ & $298 \pm 14.3^{c}$ & $252 \pm 28.3^{\mathrm{c}}$ & $410 \pm 33.7^{b}$ & $549 \pm 39.8^{\mathrm{a}}$ & $451 \pm 12.9^{b}$ \\
\hline Leucine* & $956 \pm 51.6^{\mathrm{a}}$ & $932 \pm 15.2^{\mathrm{a}}$ & $518 \pm 11.1^{\mathrm{b}}$ & $499 \pm 29.8^{b}$ & $1016 \pm 90.4^{\mathrm{a}}$ & $918 \pm 37.7^{\mathrm{a}}$ \\
\hline Tyrosine & $599 \pm 11.9^{\mathrm{b}}$ & $746 \pm 39.3^{\mathrm{a}}$ & $525 \pm 28.5^{\mathrm{c}}$ & $490 \pm 27.4^{\mathrm{c}}$ & $696 \pm 20.5^{\mathrm{a}}$ & $519 \pm 12.3^{\mathrm{c}}$ \\
\hline Phenylalanine* & $575 \pm 16.8^{\mathrm{a}}$ & $461 \pm 19.4^{\mathrm{b}}$ & $312 \pm 14.5^{\mathrm{c}}$ & $251 \pm 11.0^{\mathrm{c}}$ & $533 \pm 39.4^{\mathrm{a}}$ & $537 \pm 26.3^{\mathrm{a}}$ \\
\hline Histidine* & $180 \pm 25.8^{\mathrm{a}}$ & $124 \pm 15.8^{\mathrm{bc}}$ & $73.7 \pm 9.2^{\mathrm{d}}$ & $85.4 \pm 7.2^{\text {cd }}$ & $145 \pm 6.10^{\mathrm{ab}}$ & $130 \pm 11.8^{\mathrm{b}}$ \\
\hline Hydroxylysine & $207 \pm 24.0^{\mathrm{ab}}$ & $203 \pm 37.7^{\mathrm{ab}}$ & $75.6 \pm 11.1^{\mathrm{c}}$ & $231 \pm 56.6^{\mathrm{a}}$ & $266 \pm 31.1^{\mathrm{a}}$ & $113 \pm 1.3^{\mathrm{bc}}$ \\
\hline Lysine* & $512 \pm 24.0^{\mathrm{ab}}$ & $351 \pm 14.3^{\mathrm{c}}$ & $144 \pm 19.8^{\mathrm{d}}$ & $469 \pm 27.2^{\mathrm{b}}$ & $521 \pm 28.1^{\mathrm{ab}}$ & $574 \pm 39.3^{\mathrm{a}}$ \\
\hline TAAs & $22112 \pm 170^{\mathrm{a}}$ & $20940 \pm 285^{\mathrm{d}}$ & $12251 \pm 265^{\mathrm{d}}$ & $14375 \pm 165^{\mathrm{c}}$ & $22364 \pm 539^{\mathrm{a}}$ & $20168 \pm 286^{\mathrm{b}}$ \\
\hline TEAAs & $5090 \pm 151^{\mathrm{a}}$ & $4115 \pm 69.8^{\mathrm{b}}$ & $2597 \pm 90.7^{\mathrm{c}}$ & $2978 \pm 84.0^{\mathrm{c}}$ & $5080 \pm 167^{\mathrm{a}}$ & $5121 \pm 171^{\mathrm{a}}$ \\
\hline
\end{tabular}

Data are expressed as mean \pm standard error $(n=4)$. TAAs: Total amino acids. *: Essential amino acids; Different superscripts in the same column indicate statistical differences $(\mathrm{p}<0.05)$. 
From the results, it was found that total essential amino acids (TEAAs) ranged from $2597 \pm 90.7 \mathrm{mg} / 100 \mathrm{~g}$ to $5121 \pm 171$ $\mathrm{mg} / 100 \mathrm{~g}$ with the highest TEAAs was found in Hokkaido, Kansai and Aomori products, while the lowest one was observed for Mexico product. The most abundant essential amino acids (EAAs) in all samples were threonine, leucine and valine. The concentration of these three amino acids accounted for $(55.8 \%, 61.5 \%, 54.6 \%, 44.4 \%, 57.3 \%$ and 55.7\%) in total essential amino acids in Hokkaido, Indonesia, Mexico, Australia, Kansai and Aomori products, respectively. The result was similar to eight of dried sea cucumber species [18] and sea cucumber Stichopus japonicas [1], however, [16] found that the most abundant EAAs was lysine in dried sea cucumber Cucumaria frondosa instead of threonine in this study. The significant discrepancy in amino acid compositions between products might be due to the difference in their protein contents (Table 1), which have a positive correspondent with amino acids contents [16]; the difference of species, amino acid types and production process of dried sea cucumbers [30]. High total amount of imino acids (hydroxyproline, proline and glycine) were found in all products, which ranged from $4611 \mathrm{mg} / 100 \mathrm{~g}$ to $8240 \mathrm{mg} / 100 \mathrm{~g}$ with the highest total imino acids observed for Hokkaido product.[28] have demonstrated that the total amount of these amino acids had positively related to the content of collagen in sea cucumbers, which have a good gelforming ability and contributes to their unique texture.

\subsection{Mineral composition of dried sea cucumber products}

Mineral composition of six types of dried sea cucumber product is presented in Table 3. The most four abundant macroelements such as magnesium, calcium, potassium and sodium were determined in which the percentage of those in total mineral content were $99.96 \%, 99.92 \%, 99.98 \%, 99.90 \%, 99.91 \%$ and $99.98 \%$ in Hokkaido, Indonesia, Mexico, Australia, Kansai and Aomori products, respectively. The results were similar to the previous study for two dried sea cucumber species, including Holothuria arenicola and Actinopyga mauritiana which presented by [29] and giant red sea cucumbers Parastichopus californicus [28]. The highest total mineral content $(9947 \pm 436 \mathrm{mg} / 100 \mathrm{~g})$ was noted in Mexico product, followed by Aomori and Australia products $(6024 \pm 225 \mathrm{mg} / 100 \mathrm{~g}$ and $5217 \pm 507 \mathrm{mg} / 100 \mathrm{~g}$, respectively), while the lowest was Hokkaido product $(2693 \pm 234 \mathrm{mg} / 100 \mathrm{~g})$. The significant lower magnesium was found in Aomori product, without any significant difference $(\mathrm{p}<0.05)$ between the other five products. In addition, the highest calcium was observed for Australia product $(2724 \pm 353 \mathrm{mg} / 100 \mathrm{~g})$ and Mexico product $(1947 \pm 366 \mathrm{mg} / 100 \mathrm{~g})$, while the lowest was found in Aomori product $(61.0 \pm 31.9 \mathrm{mg} / 100 \mathrm{~g})$. Moreover, the highest potassium was obtained in Mexico product (1011 \pm 23.7 $\mathrm{mg} / 100 \mathrm{~g})$, whereas the lowest was noted in Hokkaido product $(278 \pm 21.0 \mathrm{mg} / 100 \mathrm{~g})$. Furthermore, the highest sodium was also observed for Mexico product $(6322 \pm 273 \mathrm{mg} / 100 \mathrm{~g})$, followed by Aomori product $(4912 \pm 185.2 \mathrm{mg} / 100 \mathrm{~g})$, whereas the lowest was found in Hokkaido product $(964 \pm 128 \mathrm{mg} / 100 \mathrm{~g})$. The highest microelements of manganese $(1.38 \pm 0.64$ $\mathrm{mg} / 100 \mathrm{~g})$ and chromium $(1.23 \pm 0.54 \mathrm{mg} / 100 \mathrm{~g})$ were found in Australia product and no significant difference of those for all other products. There were no significant difference in term of zinc, lead and nickel amongst six types of dried product. Copper and cadmium were not detected for all of products. High ash contents in Mexico and Australia products (Table 1) may be related to high total mineral, calcium and magnesium contents in these products [11]however, studies on nutrition value of Indonesian sea cucumbers are still beneficial due to the great diversity and uniqueness of each species. The present work was intended to obtain information about chemical composition and fatty acid profile of 4 (four. In addition, high sodium contents in Mexico and Aomori products may be due to the salt treatment in dried sea cucumber production [8].

Table 3. Mineral composition of six types of dried sea cucumber ( $\mathrm{mg} / 100 \mathrm{~g}$ dried sea cucumber)

\begin{tabular}{|c|c|c|c|c|c|c|}
\hline Elements & Hokkaido & Indonesia & Mexico & Australia & Kansai & Aomori \\
\hline Magnesium & $596 \pm 36.4^{\mathrm{a}}$ & $645 \pm 53.6^{\mathrm{a}}$ & $665 \pm 19.5^{\mathrm{a}}$ & $684 \pm 47.3^{\mathrm{a}}$ & $628 \pm 27.0^{\mathrm{a}}$ & $195 \pm 27.2^{b}$ \\
\hline Calcium & $854 \pm 220^{\mathrm{bc}}$ & $1080 \pm 283^{b}$ & $1947 \pm 366^{\mathrm{a}}$ & $2724 \pm 353^{a}$ & $650 \pm 71.3^{\mathrm{bc}}$ & $61.0 \pm 31.9^{c}$ \\
\hline Potassium & $278 \pm 21.0^{\mathrm{e}}$ & $372 \pm 72.3^{\text {de }}$ & $1011 \pm 23.7^{\mathrm{a}}$ & $477 \pm 32.5^{\mathrm{cd}}$ & $558 \pm 50.3^{c}$ & $854 \pm 49.4^{b}$ \\
\hline Sodium & $964 \pm 128^{d}$ & $1888 \pm 133^{c}$ & $6322 \pm 273^{a}$ & $1327 \pm 122^{d}$ & $1444 \pm 126^{\mathrm{cd}}$ & $4912 \pm 185^{\mathrm{b}}$ \\
\hline Zinc & $0.69 \pm 0.38^{\mathrm{a}}$ & $0.69 \pm 0.39^{\mathrm{a}}$ & $\mathrm{ND}^{\mathrm{a}}$ & $0.97 \pm 0.87^{\mathrm{a}}$ & $0.67 \pm 0.23^{\mathrm{a}}$ & $\mathrm{ND}^{\mathrm{a}}$ \\
\hline Lead & $\mathrm{ND}^{\mathrm{a}}$ & $0.79 \pm 0.79^{a}$ & $1.55 \pm 1.44^{\mathrm{a}}$ & $\mathrm{ND}^{\mathrm{a}}$ & $0.18 \pm 0.18^{\mathrm{a}}$ & $1.12 \pm 0.76^{\mathrm{a}}$ \\
\hline Manganese & $\mathrm{ND}^{\mathrm{b}}$ & $\mathrm{ND}^{\mathrm{b}}$ & $\mathrm{ND}^{\mathrm{b}}$ & $1.38 \pm 0.64^{\mathrm{a}}$ & $\mathrm{ND}^{\mathrm{b}}$ & $\mathrm{ND}^{\mathrm{b}}$ \\
\hline Nickle & $0.29 \pm 0.19^{\mathrm{a}}$ & $\mathrm{ND}^{\mathrm{a}}$ & $\mathrm{ND}^{\mathrm{a}}$ & $0.27 \pm 0.18^{\mathrm{a}}$ & $\mathrm{ND}^{\mathrm{a}}$ & $\mathrm{ND}^{\mathrm{a}}$ \\
\hline Chromium & $0.13 \pm 0.09^{\mathrm{b}}$ & $\mathrm{ND}^{\mathrm{b}}$ & $\mathrm{ND}^{\mathrm{b}}$ & $1.23 \pm 0.54^{\mathrm{a}}$ & $\mathrm{ND}^{\mathrm{b}}$ & $\mathrm{ND}^{\mathrm{b}}$ \\
\hline Cadmium & ND & ND & ND & ND & ND & ND \\
\hline Copper & ND & ND & ND & ND & ND & ND \\
\hline Total & $2693 \pm 234^{d}$ & $3988 \pm 323^{c}$ & $9947 \pm 436^{\mathrm{a}}$ & $5217 \pm 507^{\mathrm{b}}$ & $3283 \pm 143^{\mathrm{cd}}$ & $6024 \pm 225^{b}$ \\
\hline
\end{tabular}

Data are expressed as mean \pm standard error $(n=4)$. ND: Not detection; Different superscripts in the same column indicate statistical differences $(\mathrm{p}<0.05)$. 


\subsection{Body size of dried and soaked sea cucumber samples}

Body size, namely, weight, length, body wall thickness and height of spines of dried and soaked sea cucumber samples are provided in Table 4. In respect of dried sea cucumbers, the highest weight and length were observed for Indonesia product $(25.3 \pm 1.7 \mathrm{~g}$ and $77.9 \pm 2.9 \mathrm{~mm}$, respectively), followed by Hokkaido product $(14.8 \pm 0.5 \mathrm{~g}$ and $64.3 \pm 1.7 \mathrm{~mm}$, respectively) and Mexico product (15.4 $\pm 1.2 \mathrm{~g}$ and $61.0 \pm 2.7 \mathrm{~mm}$, respectively), without any significant difference $(\mathrm{p}<0.05)$ between the other three products. These results were very much lower than those of some dried sea cucumber species such as Actinopyga lecanora, Actinopyga mauritiana, Actinopyga miliaris, Bohadschia argus, Holothuria fuscogilva, Holothuria scabra, Holothuria whitmaei and Thelenota ananas [31]. No spine was found in Indonesia and Australia products and no significant difference $(p<0.05)$ in height of spine between the other four products.

For soaked sea cucumber samples, it was found that the similar highest weight and length were found in Indonesia product $(178 \pm 18.8 \mathrm{~g}$ and $173 \pm 17.6 \mathrm{~mm}$, respectively) and Hokkaido product $(175 \pm 10.4 \mathrm{~g}$ and $154 \pm 1.9 \mathrm{~mm}$, respectively), whereas the lowest were noted in Australia product $(29.2 \pm 6.8 \mathrm{~g}$ and $87.9 \pm 4.5 \mathrm{~mm}$, respectively), and no significant difference $(\mathrm{p}<0.05)$ between the other three products. Similar lower body wall thickness was found in Australia and Kansai products $(8.0 \pm 1.0 \mathrm{~mm}$ and $10.1 \pm 0.8 \mathrm{~mm}$, respectively), without any significant difference $(\mathrm{p}<0.05)$ between the other four products. [32] reported that very much higher weight and length, whereas similar the body wall thickness of some fresh sea cucumber species such as Actinopyga mauritiana, Holothuria scarab, Bohadschia marmorata compared to this study. The highest height of spine was observed for Hokkaido product $(8.16 \pm 0.7 \mathrm{~mm})$, followed by Aomori product $(6.18 \pm 0.2 \mathrm{~mm})$, finally Kansai and Mexico products, no spine was observed for Indonesia and Mexico products. From these results, it can be seen that the highest weight, length, body wall thickness and height of spine of soaked sea cucumber sample from Hokkaido product may be the reasons which contribute to its high commercial values [3].

Table 4. Body size of six types of dried and soaked sea cucumber product

\begin{tabular}{|c|c|c|c|c|c|c|c|}
\hline \multirow{2}{*}{ Products } & \multicolumn{3}{|c|}{ Dried sea cucumber } & \multicolumn{4}{|c|}{ Soaked sea cucumber } \\
\hline & Weight (g) & $\begin{array}{c}\text { Length } \\
\text { (mm) }\end{array}$ & $\begin{array}{c}\text { Height of } \\
\text { spine (mm) }\end{array}$ & Weight (g) & $\begin{array}{l}\text { Length } \\
(\mathrm{mm})\end{array}$ & $\begin{array}{c}\text { Body wall } \\
\text { thickness }(\mathrm{mm})\end{array}$ & $\begin{array}{l}\text { Height of spine } \\
(\mathbf{m m})\end{array}$ \\
\hline Hokkaido & $14.8 \pm 0.5^{\mathrm{b}}$ & $64.3 \pm 1.7^{\mathrm{b}}$ & $4.0 \pm 0.0^{\mathrm{a}}$ & $175 \pm 10.4^{\mathrm{a}}$ & $154 \pm 1.9^{\mathrm{a}}$ & $14.0 \pm 0.7^{\mathrm{a}}$ & $8.16 \pm 0.7^{\mathrm{a}}$ \\
\hline Indonesia & $25.3 \pm 1.7^{\mathrm{a}}$ & $77.9 \pm 2.9^{\mathrm{a}}$ & & $178 \pm 18.8^{\mathrm{a}}$ & $173 \pm 17.6^{\mathrm{a}}$ & $14.0 \pm 1.3^{\mathrm{a}}$ & \\
\hline Mexico & $15.4 \pm 1.2^{\mathrm{b}}$ & $61.0 \pm 2.7^{\mathrm{b}}$ & $2.2 \pm 0.2^{\mathrm{a}}$ & $96.6 \pm 7.0^{\mathrm{b}}$ & $117 \pm 3.6^{\mathrm{b}}$ & $13.0 \pm 1.1^{\mathrm{ab}}$ & $3.20 \pm 0.3^{\mathrm{c}}$ \\
\hline Australia & $4.0 \pm 0.6^{\mathrm{c}}$ & $44.8 \pm 1.6^{\mathrm{c}}$ & & $29.2 \pm 6.8^{c}$ & $87.9 \pm 4.5^{\mathrm{c}}$ & $8.0 \pm 1.0^{\mathrm{c}}$ & \\
\hline Kansai & $4.9 \pm 0.6^{\mathrm{C}}$ & $43.8 \pm 2.8^{\mathrm{c}}$ & $1.3 \pm 0.3^{\mathrm{a}}$ & $65.2 \pm 7.3^{\mathrm{b}}$ & $111 \pm 2.7^{\mathrm{bc}}$ & $10.1 \pm 0.8^{\mathrm{bc}}$ & $3.38 \pm 0.3^{\mathrm{c}}$ \\
\hline Aomori & $6.5 \pm 0.8^{\mathrm{c}}$ & $45.6 \pm 4.7^{\mathrm{c}}$ & $2.4 \pm 0.2^{\mathrm{a}}$ & $69.8 \pm 6.2^{\mathrm{b}}$ & $121 \pm 3.0^{\mathrm{b}}$ & $11.1 \pm 0.8^{\mathrm{ab}}$ & $6.18 \pm 0.2^{\mathrm{b}}$ \\
\hline
\end{tabular}

Data are expressed as mean \pm standard error $(n=4)$. Missing data in the above table indicates no spine Different superscripts in the same column indicate statistical differences $(\mathrm{p}<0.05)$.

From the results, although lower weight and length in dried sea cucumber from Hokkaido product than Indonesia product was observed, there was no significant difference of those in their soaked sea cucumbers. The results may be due to the higher rehydration ratio found in Hokkaido product than Indonesia product (Table 4), which contribute to larger body size increase of Hokkaido product than Indonesia product during soaking process because there was a balance between the amount of absorbed water and body size increase [33] 60, and 80lu00b0C. A similar trend was observed for Kansai and Aomori products which were lower weight and length in dried sea cucumber than Mexico product; however, there was no significant difference of those in their soaked sea cucumbers. The results also may be explained by the higher rehydration ratio in Kansai and Aomori products than Mexico product (Table 4).

\subsection{Texture, rehydration ratio and moisture content of soaked sea cucumber samples}

Texture, rehydration ratio and moisture content of soaked sea cucumber samples are shown in Table 5. It can be seen that Indonesia and Mexico products showed the similar highest hardness (5.308 $\pm 0.928 \mathrm{~N}$ and $4.205 \pm 0.190 \mathrm{~N}$, respectively), while the lowest was found in Australia and Kansai products (2.718 \pm 0.159 N, $1.419 \pm 0.195$ N, respectively). Similar 
results were observed for the chewiness. Indonesia and Mexico products gave the highest chewiness $(5.053 \pm 0.868 \mathrm{~N}$ and $4.156 \pm 0.219 \mathrm{~N}$, respectively), whereas the lowest were Australia and Kansai products $(2.326 \pm 0.111 \mathrm{~N}, 1.374 \pm 0.197 \mathrm{~N}$, respectively). However, Hokkaido product had the highest springiness (1.025 \pm 0.005$)$, whereas the lowest was Australia product $(0.943 \pm 0.024)$, and no significant difference $(\mathrm{p}<0.05)$ between the other four products. In addition, lower cohesiveness was noted in Australia product $(0.932 \pm 0.024)$ than the other five products, which were not significantly different $(p<0.05)$. A study on rehydration of dried sea cucumber was carried out by [12] rapid and non-invasive NMR and MRI method was introduced to analyze the rehydration process for dried sea cucumber. The spin-spin relaxation time (T2 reported that hardness and chewiness were $1.622 \mathrm{~N}$ and $1.534 \mathrm{~N}$, respectively, which were similar to those in Kansai product, however, very much lower than those of the other five products in this study. In addition, cohesiveness (0.93) was also similar to Australia product, but lower than those of the other five products. Moreover, springiness (0.99) was almost similar to those of soaked sea cucumber samples, exceptional higher springiness was observed for Hokkaido product.

Table 5. Texture, moisture and rehydration ratio of six types of soaked sea cucumber product

\begin{tabular}{lllllll}
\hline \multirow{2}{*}{ Products } & \multicolumn{2}{c}{ Texture } & \multicolumn{2}{c}{$\begin{array}{c}\text { Rehydration } \\
\text { ratio }\end{array}$} & Moisture (\%) \\
\cline { 2 - 5 } & Hardness (N) & Springiness & Cohesiveness & Chewiness (N) & & \\
\hline Hokkaido & $2.975 \pm 0.249^{\mathrm{b}}$ & $1.025 \pm 0.005^{\mathrm{a}}$ & $0.976 \pm 0.003^{\mathrm{ab}}$ & $2.905 \pm 0.241^{\mathrm{bc}}$ & $11.9 \pm 0.4^{\mathrm{a}}$ & $93.2 \pm 0.1^{\mathrm{bc}}$ \\
Indonesia & $5.308 \pm 0.928^{\mathrm{a}}$ & $0.965 \pm 0.006^{\mathrm{bc}}$ & $0.999 \pm 0.007^{\mathrm{a}}$ & $5.053 \pm 0.868^{\mathrm{a}}$ & $7.2 \pm 1.1^{\mathrm{b}}$ & $90.6 \pm 1.1^{\mathrm{d}}$ \\
Mexico & $4.205 \pm 0.190^{\mathrm{ab}}$ & $0.984 \pm 0.003^{\mathrm{b}}$ & $1.009 \pm 0.002^{\mathrm{a}}$ & $4.156 \pm 0.219^{\mathrm{ab}}$ & $6.4 \pm 0.6^{\mathrm{b}}$ & $92.3 \pm 0.6^{\mathrm{cd}}$ \\
Australia & $2.718 \pm 0.159^{\mathrm{bc}}$ & $0.943 \pm 0.024^{\mathrm{c}}$ & $0.932 \pm 0.024^{\mathrm{b}}$ & $2.326 \pm 0.111^{\mathrm{cd}}$ & $7.2 \pm 0.9^{\mathrm{b}}$ & $94.7 \pm 0.6^{\mathrm{ab}}$ \\
Kansai & $1.419 \pm 0.195^{\mathrm{c}}$ & $0.981 \pm 0.004^{\mathrm{b}}$ & $0.994 \pm 0.006^{\mathrm{a}}$ & $1.374 \pm 0.197^{\mathrm{d}}$ & $13.3 \pm 0.2^{\mathrm{a}}$ & $96.0 \pm 0.2^{\mathrm{a}}$ \\
Aomori & $3.538 \pm 0.445^{\mathrm{b}}$ & $0.969 \pm 0.004^{\mathrm{bc}}$ & $0.974 \pm 0.011^{\mathrm{ab}}$ & $3.313 \pm 0.405^{\mathrm{bc}}$ & $11.0 \pm 1.0^{\mathrm{a}}$ & $96.1 \pm 0.7^{\mathrm{a}}$ \\
\hline
\end{tabular}

Data are expressed as mean \pm standard error $(n=4)$. Different superscripts in the same column indicate statistical differences $(p<0.05)$.

Kansai, Hokkaido and Aomori products had similar higher rehydration ratio $(13.3 \pm 0.2,11.9 \pm 0.4$ and $11.0 \pm 1.0$, respectively) than the other three products, which was not significantly different $(\mathrm{p}<0.05)$. Similar results have been obtained in moisture contents. Kansai, Aomori and Australia products had the highest moisture content $(96.0 \pm 0.2 \%$, $96.1 \pm 0.7 \%$ and $94.7 \pm 0.6 \%$, respectively), whereas the lowest was Indonesia product $(90.6 \pm 1.1 \%)$, without any significant difference $(p<0.05)$ between the other two products. Rehydration ratio of dried sea cucumber (11.8) was reported by [12]a rapid and non-invasive NMR and MRI method was introduced to analyze the rehydration process for dried sea cucumber. The spin-spin relaxation time (T2, which was similar to those in Hokkaido, Kansai and Aomori products, but higher than those in Indonesia, Mexico and Australia products in the present study. In the contrary, [8] reported that rehydration ratio of dried sea cucumber Stichopus japonicus (7.6) was very close to those in Indonesia, Mexico and Australia products, however, much lower than those in Hokkaido, Kansai and Aomori products. In addition, [8] and [12]a rapid and noninvasive NMR and MRI method was introduced to analyze the rehydration process for dried sea cucumber. The spin-spin relaxation time (T2 reported that moisture contents of soaked sea cucumbers were $93.8-94.1 \%$ and $90 \%$, respectively which were close to moisture contents for all of samples in the present study.

From these results, it was found that higher rehydration ratio and moisture content in Kansai, Hokkaido and Aomori products matched well with their low hardness and chewiness. This reason can be explained by the high rehydration ratio and moisture content could have a high water-protein interaction and low protein-protein interaction or might be due to the higher increase in the fiber bundle space presence of larger extracellular space which facilitate the water penetration into the enlarged space and resulted in high extracellular water content, leading to low hardness and chewiness [12] a rapid and non-invasive NMR and MRI method was introduced to analyze the rehydration process for dried sea cucumber. The spin-spin relaxation time (T2. The highest springiness in Hokkaido product may be due to spices because each sea cucumber has unique texture characteristics [7]. In addition, lower rehydration and harder texture in Indonesia and Mexico products may be due to the protein denaturation during the boiling process in dried sea cucumber production [34], which led to reduce the hydrophilic groups available for water - binding sites [12] a rapid and non-invasive NMR and MRI method was introduced to analyze the rehydration process for dried sea cucumber. 
The spin-spin relaxation time (T2. Thus, texture and rehydration ratio of dried sea cucumbers depend on species [7] and processing [34], [20] and reduce energy consumption, we dried sea cucumber using three different drying methods, namely, electrohydrodynamic (EHD. In addition, good texture is defined as body wall of sea cucumber with some springiness, without hard or soft [7]. Thus, Hokkaido product had the best texture due to its highest springiness [7] and highest rehydration ratio which may be the reasons contributing to its high commercial values [3].

\subsection{Color of soaked sea cucumber samples}

$L^{*}, a^{*}$ and $b^{*}$ values were used to determine the color of soaked sea cucumber samples (Table 6), which indicated the lightness, redness and yellowness, respectively. The $L^{*}, a^{*}$ and $b^{*}$ values for all of soaked sea cucumber samples varied with different products $(\mathrm{p}<0.05)$. As seen from $L^{*}$ values, soaked sea cucumber from Australia product had the lightest ( $L^{*}$ values of 38.3 \pm 1.9 ), followed by Indonesia product ( $L^{*}$ values of $\left.25.0 \pm 3.0\right)$ and Mexico product $\left(L^{*}\right.$ values of 27.5 \pm 1.8 ), whereas Hokkaido, Kansai and Aomori products had the similar darkest. In addition, least red color was observed for Australia product with $a^{*}$ value of $0.34 \pm 0.8$, without any significant difference in $a^{*}$ values between the other five products. On the other hand, the most yellow was found in Indonesia product with $b^{*}$ value of $8.54 \pm 1.4$, which was similar to Mexico product ( $b^{*}$ value of $7.05 \pm 0.3$ ) and Hokkaido product $\left(b^{*}\right.$ value of 5.76 \pm 1.2 ), but significantly higher than those of the other three products. The different color between products may be due to the different color of substrates and water depth [35]; habitats, morphological features and genetic relationships [36].

Table 6. Color of six types of soaked sea cucumber product

\begin{tabular}{lccc}
\hline Samples & \multicolumn{3}{c}{ Color } \\
& $\boldsymbol{L}^{*}$ & $\boldsymbol{a}^{*}$ & $\boldsymbol{b}^{*}$ \\
\hline Hokkaido & $21.1 \pm 1.2^{\text {cd }}$ & $3.99 \pm 0.8^{\mathrm{a}}$ & $5.76 \pm 1.2^{\mathrm{abc}}$ \\
Indonesia & $25.0 \pm 3.0^{\mathrm{bc}}$ & $3.00 \pm 1.4^{\mathrm{a}}$ & $8.54 \pm 1.4^{\mathrm{a}}$ \\
Mexico & $27.5 \pm 1.8^{\mathrm{b}}$ & $4.58 \pm 0.2^{\mathrm{a}}$ & $7.05 \pm 0.3^{\mathrm{ab}}$ \\
Australia & $38.3 \pm 1.9^{\mathrm{a}}$ & $0.34 \pm 0.8^{\mathrm{b}}$ & $5.23 \pm 1.2^{\mathrm{bcd}}$ \\
Kansai & $16.9 \pm 1.8^{\mathrm{d}}$ & $3.08 \pm 0.3^{\mathrm{a}}$ & $2.78 \pm 0.4^{\mathrm{d}}$ \\
Aomori & $16.3 \pm 1.2^{\mathrm{d}}$ & $3.97 \pm 0.5^{\mathrm{a}}$ & $3.59 \pm 0.7^{\mathrm{cd}}$ \\
\hline
\end{tabular}

Data are expressed as mean \pm standard error $(n=4)$. Different superscripts in the same column indicate statistical differences $(p<0.05)$.

\section{Conclusion}

Six types of dried sea cucumber product not only provide good protein and amino acids sources, but also give good mineral contents for human consumption. The unique of texture characteristics of soaked sea cucumbers contribute to good taste for customers. The best texture, largest weight, length, body wall thickness and highest height of spines in Hokkaido product provide its best quality and high commercial value. Further, the quality of dried and soaked sea cucumbers was affected by the drying and soaking processes. Therefore, it is necessary to study the optimization of the drying and soaking processes to improve the quality of final products.

\section{References}

[1] X. Duan, M. Zhang, A. S. Mujumdar, and S. Wang, "Microwave freeze drying of sea cucumber (Stichopus japonicus)," J. Food Eng., vol. 96, no. 4, pp. 491-497, Feb. 2010.

[2] Widianingsih, M. Zaenuri, S. Anggoro, and H. P. S. Kusumaningrum, "Nutritional Value of Sea Cucumber [Paracaudina Australis (Semper, 1868)]," Aquat. Procedia, vol. 7, pp. 271-276, 2016.

[3] N. P. Brown and S. D. Eddy, Echinoderm Aquaculture. JohnWiley \& Sons, Inc., Hoboken, New Jersey, 2015.

[4] Y. Natan, P. A. Uneputty, Y. A. Lewerissa, and J. A. Pattikawa, "Species and size composition of sea cucumber in coastal waters of UN bay, Southeast Maluku, Indonesia," Int. J. Fish. Aquat. Stud., vol. 3, no. 1, pp. 251-256, 2015. 
[5] L. N. Zamora and A. G. Jeffs, "Evaluation of transportation methods of juveniles of the Australasian sea cucumber, Australostichopus mollis,” Aquac. Res., vol. 46, pp. 2431-2442, 2015.

[6] S. W. Purcell, "Value, market preferences and trade of Beche-de-mer from Pacific Island sea cucumbers," $P L o S$ One, vol. 9, no. 4, pp. 1-8, 2014.

[7] T. H. Lo, "Valuation of sea cucumber attributes through laddering," SPC Beche-de-mer Inf. Bull., vol. 20, pp. 3437, 2004.

[8] T. Fukunaga, M. Matsumoto, T. Murakami, and K. Hatae, "Effects of soaking conditions on the texture of dried sea cucumber," Fish. Sci., vol. 70, pp. 319-325, 2004.

[9] N. P. Özer, S. Mol, and C. Varl1k, "Effect of the Handling Procedures on the Chemical Composition of Sea Cucumber," Turkish J. Fish. Aquat. Sci., vol. 4, pp. 71-74, 2004.

[10] E. Tanikawa, "Studies on the proteins of the meat of sea cucumber (Stichopus Japonicus Selenka)," Mem. Fac. Fish. HOKKAIDO Univ., vol. 3, no. 1, pp. 1-91, 1955.

[11] Y. N. Fawzya, I. H. Januar, R. Susilowati, and E. Chasanah, "Chemical composition and fatty acid profile of some Indonesia sea cucumbers,” Squalen Bull. Mar. Fish. Postharvest Biotechnol., vol. 10, no. 1, pp. 27-34, 2015.

[12] S. Geng et al., "A non-invasive NMR and MRI method to analyze the rehydration of dried sea cucumber," Anal. Methods, vol. 7, no. 6, pp. 2413-2419, 2015.

[13] Helrich, K. (1990) Official Methods of Analysis of the Association of Official Analytical Chemists, 15 th Editi. Association of Official Analytical Chemists, INC, USA.

[14] S. S. G. Folch J, Lees M, “A simple method for the isolation and purification of total lipides from animal tissues," J Biol Chem., vol. 226, no. 1, pp. 497-509, 1957.

[15] Y. Deng et al., "Drying-induced protein and microstructure damages of squid fillets affected moisture distribution and rehydration ability during rehydration," J. Food Eng., vol. 123, pp. 23-31, 2014.

[16] Y. Zhong, M. A. Khan, and F. Shahidi, "Compositional characteristics and antioxidant properties of fresh and processed sea cucumber (Cucumaria frondosa),” J. Agric. Food Chem., vol. 55, pp. 1188-1192, 2007.

[17] J. Mamelona, R. Saint-Louis, and É. Pelletier, "Proximate composition and nutritional profile of by-products from green urchin and Atlantic sea cucumber processing plants," Int. J. Food Sci. Technol., vol. 45, no. 10, pp. 21192126, 2010.

[18] J. Wen, C. Hu, and S. Fan, "Chemical composition and nutritional quality of sea cucumbers," J. Sci. Food Agric., vol. 90, no. 14, pp. 2469-2474, 2010.

[19] M. Y. . Ibrahim, S. M. . Elamin, Y. B. A. . Gideiri, and S. M. Ali, “The Proximate Composition and the Nutritional Value of Some Sea Cucumber Species Inhabiting the Sudanese Red Sea,” Food Sci. Qual. Manag., vol. 41, pp. $11-17,2015$.

[20] Y. Bai, M. Qu, Z. Luan, X. Li, and Y. Yang, "Electrohydrodynamic drying of sea cucumber (Stichopus japonicus)," LWT - Food Sci. Technol., vol. 54, no. 2, pp. 570-576, 2013.

[21] R. Ram, R. V. Chand, and P. C. Southgate, "Effects of Harvest and Post-Harvest Processing Methods on Quality of Beche-de-mer in Fiji Islands," J. Mar. Sci. Res. Dev., vol. 4, no. 3, pp. 2-6, 2014.

[22] F. Gao, Q. Xu, and H. Yang, "Seasonal biochemical changes in composition of body wall tissues of sea cucumber Apostichopus japonicus," Chinese J. Oceanol. Limnol., vol. 29, no. 2, pp. 252-260, 2011.

[23] Z. Liu, A. C. M. Oliveira, and Y.-C. Su, "Purification and Characterization of Pepsin-Solubilized Collagen from Skin and Connective Tissue of Giant Red Sea Cucumber (Parastichopus californicus)," J. Agric. Food Chem., vol. 58, no. 2, pp. 1270-1274, 2010.

[24] M. Zhong, T. Chen, C. Hu, and C. Ren, "Isolation and characterization of collagen from the body wall of sea cucumber Stichopus monotuberculatus.," J. Food Sci., vol. 80, no. 4, pp. 671-679, 2015.

[25] X. Gao, D. Xue, Z. Zhang, J. Xu, and C. Xue, "Rheological and structural properties of sea cucumber Stichopus 
japonicus during heat treatment," J. Ocean Univ. China, vol. 4, no. 3, pp. 244-247, 2005.

[26] S. Sai-Ut, A. Jongjareonrak, and S. Rawdkuen, "Re-extraction, Recovery, and Characteristics of Skin Gelatin.pdf," Food Bioprocess Technol, vol. 5, pp. 1197-1205, 2012.

[27] H.-L. Wu et al., "Identification of a novel gelatinolytic metalloproteinase (GMP) in the body wall of sea cucumber (Stichopus japonicus) and its involvement in collagen degradation,” Process Biochem., vol. 48, no. 5-6, pp. 871$877,2013$.

[28] P. J. Bechtel, A. C. M. Oliveira, N. Demir, and S. Smiley, "Chemical composition of the giant red sea cucumber, Parastichopus californicus, commercially harvested in Alaska,” Food Sci. Nutr., vol. 1, no. 1, pp. 63-73, 2013.

[29] M. S. Haider et al., "A study on proximate composition, amino acid profile, fatty acid profile and some mineral contents in two species of sea cucumber," J. Anim. Plant Sci., vol. 25, no. 1, pp. 168-175, 2015.

[30] Y. Deng et al., "Thermal behavior, microstructure and protein quality of squid fillets dried by far-infrared assisted heat pump drying," Food Control, vol. 36, no. 1, pp. 102-110, 2014.

[31] R. Ram, R. V. Chand, C. Zeng, and P. C. Southgate, "Recovery rates for eight commercial sea cucumber species from the Fiji Islands," Regional Studies in Marine Science, vol. 8. pp. 59-64, 2016.

[32] N. E. E. Omran, "Nutritional value of some Egyptian sea cucumbers," African J. Biotechnol., vol. 12, no. 35, pp. 5466-5472, 2013.

[33] J. A. Ulloa, C. R. Bonilla-Sánchez, M. A. Ortíz-Jiménez, P. Rosas-Ulloa, J. C. Ramírez-Ramírez, and B. E. UlloaRangel, "Rehydration properties of precooked whole beans (Phaseolus vulgaris) dehydrated at room temperature," CyTA - Journal of Food, vol. 11, no. 1. pp. 94-99, 2013.

[34] J. H. Moon and W. B. Yoon, "Size dependence of the salting process for dry salted sea cucumber (Stichopus japonicus)," J. Food Eng., vol. 170, pp. 170-178, 2016.

[35] J. Senhao, D. Shuanglin, G. Qinfeng, R. Yichao, and W. Fang, "Effects of water depth and substrate color on the growth and body color of the red sea cucumber, Apostichopus japonicus," Chinese J. Oceanol. Limnol., vol. 33, no. 3, pp. 616-623, 2015.

[36] W. Yoshida, S. Ishida, K. Ono, S. Izumi, and K. Hasegawa, "Developmental styles and larval morphology of hybridized sea cucumbers (Echinodermata: Holothuroidea)," Invertebrate Reproduction \& Development, vol. 56, no. 3. pp. 249-259, 2012. 